А. М. Поповський

\title{
ПІВДЕННО-СХІДНІ ГОВІРКОВІ РИСИ У ЗБІРЦІ ПОЕЗІЙ ІВАНА МАНЖУРИ «СТЕПОВІ ДУМИ ТА СПІВИ»
}

Поповський А. М. Південно-східні говіркові риси у збірці поезій Івана Манжури «Степові думи та співи».

У статті висвітлюються лексичні, фразеологічні, морфологічні та синтаксичні особливості південно-східних говірок, зафіксованих у поезіях Івана Манжури наприкінці XIX століття.

Ключові слова: жива народна мова, діалектна лексика; фонетичні, морфологічні, синтаксичні риси; мовно-літературна норма. 
Поповский А. М. Южно-восточные черты говоров в сборнике поэзий Ивана Манжуры «Степовые думы и песни».

В статье раскрываются лексические, фразеологические, морфологические и синтаксические особенности южно-восточных говоров, которые зафиксированы в поэзиях Ивана Манжуры в конце XIX века.

Ключевые слова: живой народный язык, диалектная лексика; фонетические, морфологические, синтаксические особенности; литературная языковая норма.

Popovs'kiy A. M. South-Eastern dialect's features in the poetry collection of Ivan Manzhura "Stepp's thoughts and songs".

In the present article the lexical, phraseological, phonetical, morphological and syntectical peculiarities of South-Eastern dialects fixed in the poetry of Ivan Manzhura at the end of the 19 th century are described.

Key words: living folk language dialect lexics, phonetical, morphological, synthectical traits, language and literary norms.

Минулися вже ті часи, коли лінгвістична оцінка особливостей діалектної мови грунтувалася на протиставленні іï літературній мові, коли першому засобу комунікації оголошувалася повна ліквідація. Чимало було втрачено для лінгвістичної науки цікавих народно-розмовних елементів (лексичних, фонетичних, морфолого-синтаксичних) у процесі усталення i кодифікації літературних норм. «Свою негативну роль зіграла й довготривала політика боротьби з усім тим українським, що з легкої руки деяких державних i культурних діячів прирівнювалася до націоналістичного ухилу, а народна мова за таких умов розвитку трактувалася як мужицька» [3, с. 3]. Настав час для глибокого проникнення в першооснови рідної мови, з'ясування особливостей розвитку різних структурних рівнів діалектів не тільки сьогодення, але й тих цінних джерелах народної мови, яку зафіксували наші попередники в різножанровій спадщині. Особливу увагу варто привернути до лексичних рівнів діалектизмів у творах українських письменників різної величини як багатогранному й цікавому об’єкту дослідження. Діалектна лексика «вимагає неодмінної уваги ще й тому, що саме слово становить поєднання результатів розвитку цілих структурних рівнів - просодії, фонетики, морфеміки, а тому може служити індикатором цих змін» [2, с. 4].

Одним із невтомних дослідників живої народної мови Південної України другої половини ХIX століття був Іван Манжура (01.XI.1851 - 15.V.1893). Багаторічна праця над збиранням та систематизацією найрізноманітніших видів усної народної творчості виробила в нього повагу й любов до повноцінного, мудрістю багатьох людських поколінь насиченого народного слова. Як досвідчений фольклорист він занотовує все нове 3 народних уст різних суспільних верств, а як поет відбирає для своїх поетичних творів найдовершеніші маловідомі слова і вводить їх в обіг загальнонародної мови, поповнюючи їі словниковий склад. 
Публікуватися Іван Манжура почав у 80-х роках на сторінках катеринославських газет і журналів (а згодом - і в галицьких виданнях) під псевдонімом Івана Калічки. Для масового читача видавав «метелики» поетичні переспіви 3 деяких популярних казкових мотивів інших літератур. При активній допомозі й підтримці О. О. Потебні, який відіграв важливу роль у формуванні світогляду та спрямуванні поетичної музи, в 1889 році вийшла друком у Петербурзі перша і єдина поетична збірка Івана Манжури «Степові думи та співи», яка «назавжди увійшла до культурної скарбниці українського народу, посівши в ній помітне місце» $[1$, с. 6].

Особливості живого народного мовлення Середньої Наддніпрянщини, Слобожанщини, Степової України, його своєрідні звороти були для поета не лише одним із джерел індивідуальної мови, характеристики персонажів, відтворення місцевого колориту, воно не могло не захоплювати як спостережливого фольклориста i мовознавця. А тому достеменності фіксації мовного матеріалу, почутого безпосередньо з народних уст, широті й повноті його охоплення він надавав особливого значення. Про свідому орієнтацію поета на народну мову в ії лексичному, граматичному багатстві та різноманітності синонімічних відтінків свідчить його лист до О. О. Потебні: «Вы ставите мне в укор провинциализмы, - писав I. Манжура, - но здесь была с моей стороны некоторая цель; именно: услыша новое слово, я заносил его в рассказ, чтобы оно не затерялось для всеобщего сведения» [3, с. 393]. Тут же поет наводить цілу низку характерних діалектних слів та виразів, подаючи їхнє тлумачення. Отже, не випадково поетичні твори Івана Манжури, зібрані ним етнографічні та фольклорні записи й досі $є$ вагомими, іноді єдиним авторитетним джерелом для українських мовознавців-діалектологів, істориків мови, дослідників стилю різних літературних пам'яток.

Як відомо, л е к с и ч н і д і а л е к т и 3 м и охоплюють переважно сфери життя, пов'язані з побутом, родинними стосунками, виробничою діяльністю носіїв степових говорів. У поезії Івана Манжури це насамперед назви сільськогосподарських угідь, рослинного й тваринного світу, природних явищ тощо, які здавна побутують серед степовиків, як-от:

- иарина «засіяне поле; посіви; лан»: Шкода на царину й глянуть бувало: Рідна ріллею чорніла, Мов сарана до стебла попсувала, Так їі суша спалила (4, с. 66);

- подім'я «подвір'я, обійстя»: Підійшов я до свого подім'я, - Щось гірке ізнов у серие уп'ялось; Те ж воно і та ж на їм будівля, Та нерідне вже над ним носилось щзось (4, с. 71);

- нежер «торішня трава»: Степ, як дим той, розіслався Просторо, широко: Мов стерня та, понавкруги Скрізь, де гляне око, Сива нежер; тільки інде Нивка половіє Недорідня, икода й праиі! Спечена марніє (4, с. 55);

- товаряка «худоба»: Скрутно прийшлася година голодна: 3 осені хліб купували; Де товаряка, одежина годна, Все те на хліб позбувати (4, с. 66); 
- nidзоряти «підглядати; наврочити, зурочити»: Як заллєш - мов позабудеш, Пішов шкандибати; Зараз людей $і$ підзорять, Та й ну дорікати $(4$, c. 89$)$;

- половіддя «Повінь»: I такий не один Повесні челядин Рвавсь, мов кінь застоялий з повіддя; Все збирався у путь, Тілько ждав, як спадуть Степовії річки з половіддя (4, с. 93);

- nутляти «сплутувати, пошкоджувати; приводити в непридатність будь-що»: Із ревищем вихор на ниву наскочив, Не икода йому ї вроди: Путля колосочки, дощенту толоче...А далі - он хмара заходе...(4, с. 69);

- смага «спека; спрага»: У тій куряві похило Стомлена ватага 3 заробітків чимчикує...Млявина та смага 3 ніг валяє небораків, Бідолах дорожніх...(4, с. 55);

- mineuь «моріг, мурава; рослина Festuca ovina»: Жайворінка озвавсь, Скрізь тіпець розіславсь, Немов килим, степом зелененьким (4, с. 93);

- заздалегоди «заздалегідь»: Tym щ⿻е ік тому мала дітвора... Заздалегоди тікай хоч з двора! (4, с. 54);

- навдаку «завдяки, спроможно, у змозі»:Навдаку тілько силоньці Та серденько моє збудить...(4, с. 50).

Незначний прошарок у поетичній спадщині становлять етнографічні діалектизми, які ввійшли в систему загальнонародної лексики без змін як єдино можливі слова для передачі означуваних ними понять. 3 цього погляду вони нагадують просторіччя чи історизми. Серед них виділяємо назви страв, інструментів, занять тощо, наприклад:

- насушник «хліб як продукт харчування»: Хіба тії побиватись Хорошої вдачі, Що насуиник дістається Мені, як собаџі (4, с. 75);

- лучок «смичок»: Стара скрипищя та лучок, Ще й невеличкий струн пучок Мені й зостались; все пропив На весіллях, щуо заробив (4, с. 77);

- ремества «народні ремесла»: Не страшно їм праці, було б біля чого Томити трудящії руки; У праці їх благо; ремества другого Хіба щуе навчаться їх внуки (4, с. 68);

- струмент «інструмент»: A кравецьь нікчемний $i$ собі за ним: «Пропадай ти, каже, - із шитвом своїм». Далі й мастер струмент в торбу ісклада... «Хай тобі з майстерством? Здоров'я шкода!» (4, с. 77).

Порівняно вужча група живомовної степової лексики, що охоплює семантичні діалектизми. До них відносять слова загальнонародної мови, які в місцевих говорах відрізняються значенням і сферою вживання. Поза текстом вони звичайно не сприймаються як відхилення від загальнонародної норми. Це насамперед слова, що мають спільні значення із загальновживаними, але відрізняються від них одним або кількома новими значеннями, наприклад:

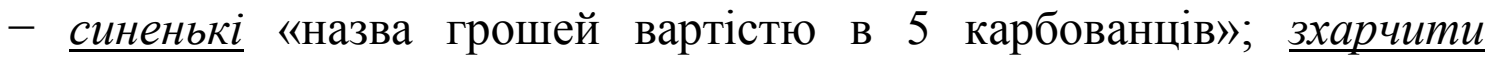
«проїсти, нічого не залишивши із заробленого»: По синенькій, дай-то Боже, Коли заробити, Та, вертаючись додому, Й те уже зхарчити; Дома ж гірша нужда кревна $(4$, с. 56); 
- naйдa «приношення, дарунок; щастя, талан; удача»: Йшла пайда козаку - Скоро став на знаку За лииарство своє він громаді; Незабаром затим Козаки кошовим Його вибрали чесно на раді (4, с. 92);

- безбаш «йти без мети, врозбрід»: Вбога ичарина змарніла, Сіножаті пожари ......... Череда он зачуміла, Бреде безбаш по горі (4, с. 85);

- датися у помку «запам'ятатися, датися взнаки»: Дасться у помку їм рік ией, зима: Ні буряка, ні капусти нема, Навіть немає мімечка картоплі; Льон не зійшов, погоріли коноплі (4, с. 54);

- зуспіти «зустріти; встигнути; несподівано з'явитися»: Пошукав би, може, чи не зуспів краю, Де сльози людської гіркої немає (4, с. 49);

- поновка «молодий мед, який ще не визрів у сотах; медова взятка»: Сумує старенький: в колодиі, Дай боже, торішній медок Коли б то задержавсь у зиму! Поновки й на палець нема... (4, с. 52).

У лексичній структурі поетичних зразків митця певне місце посідають своєрідні фразеологічні одиниці степового мовлення, як-от:

- «Якої нетечі?» - те саме, що «Якого чорта?» - уживається для вираження невдоволення: Чого мені журитися? Якої нетечі? (4, с. 75);

- жаби весільної співають «нездійсненність бажаного»: Нехай живуть пароньками, Діток наживають; Мені жаби весільної В левадах співають (4, с. 78);

- простягнутися під лісою «померти, замерзнути»: Так чого ж тут журитися? Якого ще біса? Простягнуся ж десь, як пес той, В морози під лісой (4, с. 78);

- сім раз на день пусто «те що й бити байдики; не мати ніяких підстав для пересудів»: «Хвилозопію» підпустять, «Нравственность» якусь-то...А бодай їм, божевільним, Сім раз на день пусто! (4, с. 89).

$\Phi$ о н е т и ч н і $\mathrm{p}$ и с и степових говірок у поетичних творах I. Манжури в основному відповідають сучасним мовно-літературним нормам. 3 особливостей місцевого мовлення наявні такі:

a) голосний [i] в іменникові лілія заступається [е]: У пишних палатах якогось магната Розкішні лелії ивіли...(4, с. 87);

б) вставний [ja] у дієприслівнику почувщи та дієприкметнику шумливий: Тілько вовки-сіроманиі, Труп почуявщи ураниі, У байрачі вили тяжкко...(4, с. 86); Несподівано ми із тобою колись Десь на бесіді стрілись шумлявій...(4, с. 61);

в) відсутність [л] у прикметниковій формі слова журавлині: I очима вже пас Козачина не раз Журавині ключі молоденький (4, с. 93);

г) випадний [н] в іменнику соняшник: Маки розкішні, колючий будяк, Липа пахуща, нагідки, Сояшник пишний, нікчемний будяк - Все їй іде на пожитки $(4$, с. 62$)$;

д) нетипове початкове [c] у прислівнику зусіль (літературна норма зусюди): В хмарну годину не знать $і$ відкіль Погань оия набереться; Тілько щьо бджілка додому сусіль, Враз на шура і наткнеться (4, с. 63); 
е) звукосполучення [чн] у деяких словах дисимілювалося в [шн]: Тілько б родила, а ми не ліниві, Хлібець святий праџювати. Змалку у йому кохатись привишні Темні ми сірії люде...(4, с. 66).

Серед м о р фо л о гі ч н и х о 3 н а к місцевого мовлення в поетичних творах I. Манжури широко використовуються такі:

a) дієслова I дієвідміни в 1-ій особі однини теперішнього часу мають форми без чергування [д], [т], [3], [с] з відповідними шиплячими (ход'y, крут'у, воз'y, прос'у): Чого треба тобі?.. О, тебе я просю Не вражай мого серия, лукава, Бо і так через тебе у йому носю Я глибокую рану криваву (4, с. 61); Я із військом своӥм Налетю, немов грім, Не забудете ви i до судy $(4$, c. 91$)$

б) дієслова II дієвідміни в 3-ій особі однини теперішнього часу, якщо наголос падає не на закінчення здебільшого мають форми з втраченим кінцевим [т] і підрівняні під дієслівні форми I дієвідміни (носе, просе, ходе): В кожную квітку загляне вона (бджола - А. П.), Наче й утоми немає; Носе та й носе, $і$ краю не зна, Людям та богові дбає (4, с. 62-63); Їм не хвата веселих тих Хвилин щзасливих та святих, Коли, натішившись, дитина Біжить утомлена й в коліна Ховає личенько у неньки Та просе ласки... (4, с. 70); У білій плоскінній сорочщі По пасіиі ходе дідок ... (4, с. 52); Привіта мене і скеля, Пораде могила (4, с. 73);

в) форма називного відмінка множини з флексією -е, -и іменників 3 сингулятивним суфіксом -ин- типу сел'ане, л'уде, з яких переважає перша: До села ось дочвалали, Сіли, спочивають; Оступили їх селяне, Приязно питають...(4, с. 55); Мов в золото, в краску убралась пшениия, I люде знов коси гострили (4, с. 68);

г) іменники чоловічого роду хлібороб, жайворонок у називному відмінку однини мають закінчення: -a: Жайворінка озвавсь, Скрізь тіпець розіславсь [4, с. 93]; А чи пан я? а чи дука? А чи хлібороба? (4, с. 75);

д) відповідно до префікса від- виступає од-: «Походи по спеиі ось за плугом сам, Я ж рукам трудовим одпочивок дам!» (4, с. 84); ...Де нам щастя усміхнулось Та й навіки одвернулось (4, с. 59), а до префікса звиступає із: Велике слово «рідна мати»! I горе дітям, котрим знати Його ізмалку не далось (4, с. 70); Спокусив його гріх Він ізрадив своїх, Передавсь у Стамбул до султана (4, с. 92);

е) скорочені (усічені) форми 3-ої особи однини теперішнього часу на зразок дума, зна, співа: Там кравець у голку нитку задіва, Поштрикує хутко, весело співа (4, с. 84); Привіта мене і скеля, Пораде могила (4, c. 73$)$;

є) на місці сучасного прислівника навкруг фіксується ускладнений понавкруги: Понавкруги ж гуде Орда хижа та жде, Коли дасть на грабіжку він ясу (4, с. 91), а прислівники тільки, скільки мають сталу форму тілько, скілько: А може, ще стрінемось?.. Тілько ік чому! (4, с. 65); Скілько погине робітниць святих, Вимовить інколи страшно! (4, с. 63). 
С и н т а к с и ч н i $р$ и с и степового мовлення зафіксовані в конструкціях:

a) давального відмінка 3 прийменником $\boldsymbol{\kappa}$ i його фонетичним варіантом ік: Та й ті брови чорні Позлиняли к тому...(4, с. 79); Спи ж, козаче, тихо-тихо, Хай вітрецьь тебе вітає, Тиху пісеньку співає, Поки всіх к страшному суду Янгол божий не розбуде (4, с. 86); Любов ік людині, недолею стрітій Мені проказала, сумуючи, їх... (4, с. 49); Чим він у волость подушне заплате? Чим перекриє безвехую хату? Тут щзе ік тому мала дітвора...(4, с. 54);

б) знахідного відмінка з прийменником ув: I твій погляд дерзкий в моїх думках встає Зазира мені спильна ув очі (4, с. 61);

в) давального відмінка 3 прийменником об: Один дощчкк об Миколі Випав в ранню добу...(4, с. 56);

г) орудного відмінка з прийменником пред: 3 пасіки зникнуть (щури золоті - А. П.), немов кажани Никнуть пред сонечком раннім (4, с. 63);

д) безприйменникового керування: «Геть тікай отцевського порогу: Ти чужий тепер у рідній стороні» (4, с. 72).

Отже, грунтовне опрацювання мовних особливостей поетичної збірки I. Манжури «Степові думи та співи» дало можливість виявити своєрідні лексичні, фразеологічні, фонетичні, морфологічні та синтаксичні риси степових говірок, зафіксованих наприкінці XIX ст. Такий фактичний матеріал конче потрібний для лексикографії, діалектологіï, історії української мови. Адже, як виявилося, поза увагою лінгвістів лишилися ще деякі живомовні явища, які не стали набутком лексикографічних праць, не залучені до наукового обігу. Більше того, результати дослідження стануть у нагоді для порівняльної характеристики живомовних динамічних процесів у південно-східних говірках протягом одного сторіччя.

Загалом ж своїм творчим доробком Іван Манжура зробив вагомий внесок у розвиток української літературно-національної мовної норми.

\section{Література}

1. Березовський I. П. Поетична творчість Івана Манжури / I. П. Березовський // Манжура I. І. Твори. - К. : Дніпро, 1980. - 325 с.

2. Гриценко П. Ю. Ареальне варіювання лексики / П. Ю. Грищенко. - К. : Наукова думка, 1990. - 272 с.

3. Свтушок О. М. Про стан і деякі аспекти вивчення діалектної лексики / О. М. Свтушок // Українська мова і література в школі. - 1992. - № 2.

4. Манжура I. I. Твори / I. I. Манжура. - К. : Держлітвидав УРСР, 1961.

Стаття надійшла до редакиї 21.10.2010 p. 